\title{
The Americans: Domesticity and Regendering of Classical Spy Narratives
}

\begin{abstract}
In this article an analysis is made of the first season of the television series The Americans from a cultural perspective which shows the relevance of the series within the context of the first decades of the $21^{\text {st }}$ century. The series belongs to a specific genre that used to be masculine and mainly centered on the conflicts resulting from the confrontation between individual male loyalties and their identities conditioned by their belonging to a political order. By humanizing the usual villains in the spy genre, the series introduces a certain moral ambiguity and the idea that political ideologies lose their value in the face of individual motivations. This article explores the use of the conventions of the spy genre and how the model is adapted to allow for the treatment of present-day concerns related to the individual's struggle (now female as well) to reconcile public and private life.
\end{abstract}

\section{Keywords}

Spy genre; female spies; public vs private; professional women/family; individual isolation

\section{Introduction}

In the years after World War II and during the Cold War, there was a pressing need for inhabiting a 'safe place' that had to be protected from the destruction that World War II had caused. And it is precisely this vulnerability of citizens' homes and by extension of their nations that functions as "ideological motivation" for spies. But the paradox lies in the fact that "to protect domestic security for everyone else the spy must relinquish it himself" (Goodman 2016: 142-149). 
Furthermore, this tension between domestic and social security "functions as an ideological motivator" (Goodman 2016: 149) because the spy as an individual feels the need to protect his/her home environment at the same time that he/ she protects the nation. The classical spy protagonist - almost always male - is mainly known for his actions, as his feelings are not evident at first sight and his most obvious affective bonds are with his comrades. They are men without a past or history, only that which is related with their work as spies. The spy is as mysterious and secret as his work because he/she "by definition, eludes representation" (Hepburn 2005: XV. The lack of a family and the impossibility of having a domestic life are a very usual characteristic of spies' lives. Their private lives, always ephemeral and subordinate to their professional lives, respond to and "illustrates the ambivalence of power towards the spy in its pursuit of an objective" (Goodman 2016: 164).

In contrast with these classical narratives with a lonely male spy as protagonist, The Americans (2013-) complies with and breaks with generic conventions at the same time. American television series in general, and police dramas in particular, have evolved from the 1980s onwards towards the crossing of generic boundaries and hybridity. Police dramas, closely related to espionage stories in terms of narrative, started the strategy of combining "the serial structure of their melodramatic plots with a more contained, case-based narrative, typically closing down these procedural arcs within one or two episodes" (Nichols-Pethick 2012: 35 ). The Americans mixes elements such as espionage, romance and the latest addition: family life from a different ideological and ethnic perspective. Moreover, the uniqueness of the series lies in the deep attention paid to domesticity and, from the point of view of Easterners, spies working for the KGB. By mixing the extraordinary, uncommon work of spies with the daily life of a middle-class family the series creates an innovative narrative connected with the concerns of the contemporary audience in which protection of the private sphere occupies a privileged position. The couple formed by Elizabeth and Philip Jennings struggle to combine their work as spies, their duties as parents raising teenagers and the difficulties of their own romantic relationship, and all these issues are represented with verisimilitude. This tension between personal and secret life has become a characteristic of contemporary spy movies and the real dramatic core of the plot. The strategy of putting female characters front and centre to introduce romance and the personal in crime series was already used as early as 1981, when Cagney \& Lacey - a cop show - was "the first dramatic program in TV history to start two women in the leading roles" (D'Acci 1994: 5). This tendency was developed more recently in spy films such as Nikita (Luc Besson 1990), Mr. and Mrs. Smith (Doug Liman 2005) or in television series like Alias (ABC 2001-2006), Nikita (The CW 2010-2013) and Homeland (Fox 2011-). All of the aforementioned series and films are 21 st century products where women become the protagonists, initiating the path that is developed to further narrative complexities in The Americans especially through Elizabeth's character. The inclusion of a communist married woman, a mother and a high-ranking spy character 
- Elizabeth - portrayed with a complex and rounded personality, brings her closer to $21^{\text {st }}$ century women and opens up completely new possibilities for the genre. The purpose of this paper is to discuss how The Americans is, on the one hand, faithful and genuine in its generic characteristics as a spy narrative but, on the other hand, how it expands and transforms the genre to rebuild traditional gender configurations by portraying domesticity in new ways more closely related with contemporary family models. By means of reexamining the 1980's political context and people's anxieties in those days and with a major focus on domesticity and personal life, The Americans comments on and reflects $21^{\text {st }}$ century individuals and society. The Americans, even if more focused on the personal side, is not a parody of the classical spy movie but a rewriting, a tendency that Strinati defines as "reinventing and reviving genres and establishing their contemporary relevance [...] far from merely recycling the past (trying) to update cinematic images and themes" (2005: 233).

The Americans is a $21^{\text {st }}$ century TV series produced by Joe Weisberg and set in the US during Reagan's presidency. The show, as a spy narrative, is expected to be about the geopolitical spheres of the $1980 \mathrm{~s}$, but is actually more centered on the personal sphere and on troubled family relationships. The Americans is partly episodic in structure - it develops and resolves a mission over the course of an episode - and partially retains the structure of a serial drama that draws on the contemporary tendency towards hybridization in American TV shows. The first season, the object of this analysis, consists of 13 episodes and was released in 2013. The protagonists are two Soviet agents, a man and a woman, selected by the KGB, who pretend to be husband and wife. The Jennings, Elizabeth (Kerri Russell) and Philip (Mathew Rhys) have lived for almost two decades in the United States and are indistinguishable from a real American family. During the day they work as travel agents and attend their duties as parents, but it is mostly at the night that they 'escape' from home and conduct their activities as secret agents. When the series starts, Elizabeth and Phillip's private lives are almost a complete fake. Only their parenthood is genuine, while in everything else, including their relationship as a couple, they are apparently acting on KGB orders. Moreover, they do not even know each other's real name, only their personal story, invented by the KGB. Elizabeth and Philip have their counterparts in the CIA agents Stan Beeman (Noah Emmerich) and his wife Sandra Beeman (Susan Misner), who are paradoxically and, at the same time, their enemies and their best friends. Philip and Elizabeth 's marriage is constantly tested, not by any remorse related to their criminal acts (murdering, kidnapping and lying) but by their 'out of duty' sexual relationships and lies. They constantly disguise themselves in costumes and sleep with other people. Their children, Paige (Holly Taylor) and Henry (Keidrich Sellati) are an essential part of their covert but live unaware of their parents' secret work and behaviour. In this first season, Philip is tempted by the idea of becoming a 'real' American in contrast to Elizabeth who is totally committed to the ideals and interests of communism. 


\section{Spy narratives in context: The cold war}

Spy novels - frequently the source and generic origin of spy films - are narratives that, by means of the use of intrigue and violence, "typically speculate on what constitutes an individual's belonging to a political order" (Hepburn 2005: 8). They show individuals trying to find a sense of identity in contrast with a world that is shifting so fast and radically (Classen 2011: n.p.). The climate of distrust in which these spy films were released was the consequence of some significant events:

The next major turn in the pattern of the spy film was prompted by American events which evoked dominant moods of suspicion and conspiracy - even paranoia: The assassinations of the Kennedys and King; the Vietnam War; the squalidness of the Watergate affair; the revelation of intelligence agencies run rampant. As each affair was publicized, it was revealed so inadequately and suspiciously that the public mood of mistrust and fear for its democratic institutions became a national obsession. (Booth 1991: 152)

Prior to these historical events, in the 1950s a historical period started which was marked by the development of social movements advocating the rights of minorities, especially in America: the counterculture or hippy movement, African American Civil Rights, Women's rights, the Gay rights movement, the Hispano and Chicano movement among others. As a reaction to these numerous movements, in the late 1970s and more intensively in the 1980s -the historical context in which The Americans is set -, there was a conservative backlash in America to stem the tide of change. The consequence was an ultra-conservative as president of the US for most of the decade. ${ }^{1}$

American and British espionage movies from the Cold War period are always made from the perspective of the West Bloc. In the first decades after World War II, spy narratives were almost propaganda, a useful tool to spread a political message. Early John Le Carré novels and Bond films depict the other bloc, politically incompatible, as "dangerous subversion which had to be stopped at all costs" (Jarausch et al 2017: 10). The audience usually knows at first hand the names, faces and movements of westerners, whereas those belonging to the Soviet Bloc remain in the shadows, unidentified, not even individuals but a kind of mass. Initially the bipolar classification of the 'goodies' - capitalists - versus the 'baddies' - communists - is reflected in cultural representations, in which spies become contenders "whose struggles illustrated the implications of a belief system" (Jarausch et al 2017: 17).

Spy narratives are morally ambiguous since treachery is intrinsically linked with the spy's activities. Furthermore, as Hepburn points out, "spies deal with betrayal and double-crosses the way detectives deal with motives and crimes" (2005: 25). Spy movies would be film 'gris' because, even if they are not film noir in a generic sense, their mood is dark, with a certain sense of fatality, decadence, 
suspiciousness and loneliness. Spies have a perilous way of life that frequently gets them killed and even when they win their losses are enormous. There is always some westerner who defects to the other bloc, a mole, and someone from the other bloc who has some 'treasure' and the spy does his best to discover what their secret is. Although there is sex in their stories, it is not as omnipresent as in the fantastic trend represented by James Bond in which sex with stunning women becomes the male protagonist's reward. ${ }^{2}$

The spies' world exists in binary terms. Besides the opposition domestic-private/ public-professional, there is also ideological binarism. The spy belongs to and fights for either capitalism or communism but both political and social blocs are portrayed as incompatible. Spies also have to make a choice between being faithful to their mother countries and defecting to the other bloc. As Eco contends, these binarisms are:

Very similar to Lévi Strauss's binary oppositions [...] that involve the relation between characters, between ideologies, for example, between liberalism and totalitarianism, or the 'free world' and the 'Soviet Union' and a large number of relations between distinct types of values such as 'cupidity- ideals', love-death, chance-planning, perversion-innocence, loyaltydisloyalty. (in Strinati 2005: 93-94)

It seems that this loyalty choice, in the realistic trend, becomes a moral rather than a political issue. Usually the defector who voluntarily leaves and betrays his/ her side is moved either by personal affections towards the protagonist, or mainly by greediness instead of by his/her political views. Moreover, in spy narratives with few exceptions, in a reaffirmation of binarisms, there is only one correct and right side to be on while the other will always be evil and wrong.

\section{The Americans in context}

If the Cold War was a period of anxiety for western countries, we are reliving a period of fear and paranoia in the first decades of the $21^{\text {st }}$ century. Nowadays, in western countries and according to Bleton, we have inherited an ideological binarism in which there is an "Islamic foe simply replacing the Soviet one" (2017: 151). Today our main threat comes from Islamic fundamentalism. The Americans comments on American society, politics and family life in Reagan's time. But this image can be extrapolated to our times in which, instead of the Soviet Union, terrorism is the threat. If classical spy fiction such as that written by le Carré, Greene, Fleming and Deighton "demonstrated that the house, and by extension the nation, is constantly vulnerable to attack from outside forces" (Goodman 2016: 143), the rebirth of the genre in current times is not uncommon but perfectly justified. US civilian citizens learned after $9 / 11$ that they were vulnerable to foreign attacks in their own country and this feeling of being under the 
spotlight can be equated to the atmosphere in Cold War times. In this context of anxiety "the spy embodies fears that national identity is under threat and that in order to maintain the status quo, clandestine activities normally considered illegal or invasive must be endorsed" (White 2007: 1). Spy films justify moral ambiguity, their protagonists fight a covert war and, as the saying goes, "all is fair in love and war". The Americans recalls how morally questionable strategies were justified and used in the past, and how they could have shaped our present.

Initially the series is built on binary oppositions, following the typical structure used in realistic spy movies of personal, social, and political symmetry. In the series' universe one has to be faithful either to the US or to Russia, there is no middle ground. But this initial classical binarism is subverted in The Americans because everyone has at least two sides in the series. As Natasha Walter rightly points out, this radical polarization between the "good side and the bad", which is the general trend in classical spy fiction, results in barely authentic portrayals of "our complicated reality" (2016: n.p.). Moreover, in Ernest Mandel's words:

Life is based on double standards [...] hence the individual drama, based on the contradiction between social norms and personal needs. Under normal conditions, this contradiction is restrained and repressed, especially when personal needs are frustrated. Crime and spy stories release these inhibitions, frustrations, and repressions, and allow the contradictions to flower. (1984: 65)

Elizabeth and Philip Jennings have been living in the US for 20 years and have two American children. Their political loyalty with communism is potentially inconsistent with their love as parents of two American children, and even with their romantic relationship as a couple, a relationship strictly prohibited by the KGB. This is why defecting can turn into a moral rather than a political decision. The characters are rounded episode by episode, changing and evolving in a demonstration of the inadequacy of black and white thinking when applied to human beings.

\section{Spies: gender models and roles}

The traditional protagonist in a classical spy movie is a western man without family bonds. Romances are unusual and short-term stories, because very often the spy's lover eventually dies. Furthermore, romance, although not a usual ingredient in the 'formula', is sometimes used as a way of testing the typical male spy's physical invulnerability to feelings such as love, sadness or happiness in a context where love is considered an intolerable weakness (Hepburn 2005: 14). All his life, time, and efforts are devoted to his work as a spy. Even though women were present from the very beginning in classic spy narratives, they were clichés rather than rounded and evolved characters, usually falling into the four catego- 
ries named by Tom Lisanti and Louis Paul: "the helpful spy $[\ldots]$ the innocent $[\ldots]$ the bad-girl-turned good [...] [and] the villainess/femme fatale/assassin" (2002: 14-16). Furthermore, communist female agents were divided into two types: the "emotionless, authoritarian and desexualized [...] [and] the beautiful Mata Hari-type" (Kackman 2005:34). Both female characters are outside the expected gender roles but only in a 'negative' sense since they may represent stereotypes, not real women. It seems that the spy genre has still left little room for women up to the present day. As recently as 2016, Natasha Walter has called for a wider presence of women protagonists in spy narratives since she finds them so "rigidly masculine" that women are usually reduced to "sexualized bodies" and the object of the male gaze, "subsumed into the needs and desires of the male hero". Women are denied "access to full information" and when acting, they do so "purely out of disinterested loyalty and love" (2016: n.p.).

In The Americans, instead of the solitary male spy there is also a woman that is not a mere embellishment in the plot. Moreover, the main character seems to be Elizabeth because in the 'spy rank' she is highly thought of by her superiors and usually receives the orders first. The great novelty of the series is twofold: on the one hand, the protagonist is a non-western couple and on the other hand, breaking the usual expectations, the woman is the harder of the pair and mainly responsible to her authorities. According to Rosie White the female spy is twice as transgressive as her male comrade/counterpart but her representation is not free from contradictions because she "represent[s] an uneasy rapprochement between women spies as agents/subjects and as objects" (2007: 4).

The Americans' renewal of the genre by means of using significantly different protagonists can be seen in the way it adapts an 'old' genre more suited to contemporary times rather than trying to make a postmodern parody of secret agent films. Elizabeth, in line with previous characters such as Nikita in Nikita (1990), Sydney Bristow in Alias (2001-2006) or Jane Smith in Mr. and Mrs. Smith (2005), challenges male supremacy in spy fiction. Elizabeth has a leading role as a spy in her own right but at the same time her character is narratively more complex since she is also a conventional mother and wife. Domesticity/family life and romance are incorporated into the diverse threads of the plot sometimes acquiring a more important level than the espionage thread. It is this intention of expanding the narrative possibilities of the genre to deal with complex personal subjects that makes The Americans a text engaged with present times.

Elizabeth is a worried mother, murderer and femme fatale at the same time. She fulfills the prototypical femme fatale type in noir films when it is necessary for her job as a spy - sexualized and threatening to men. Elizabeth simultaneously embodies two 'threatening' models of the communist female spy: the coldblooded killer - ideologically and mentally strong - and the femme fatale able to use her body to seduce men and get information. But even if Elizabeth initially embodies the stereotype, she also subverts it by combining contradictory models of women in a single character. From the working mother to the perfect middleclass housewife, from the faithful wife to the whore, from the American citizen to 
the Russian communist spy, from the implacable murderer to the mother worried about her family's safety. All these contradictions shape the complicated identity she struggles to reconcile. But Elizabeth is more than a spy: she is a human being, with all the facets and complications of a real woman. She suffers not only from professional but also from personal anxiety. She, like many contemporary working mothers in real life, tries to reconcile her role as a mother with her work as a spy. Her children and the beginning of a desire for a real romantic relationship with Philip are her weaknesses and the force that to some extent conditions her evolution through the series. Unlike previous Russian and other non-American female agents, Elizabeth has a genuine interest in and love for her children. But it should not be forgotten that her role as mother entirely belongs to her 'American side', that she is an American mother because her maternity fully belongs to the model American family invented for the purpose of providing the perfect covert. Although in the traditional spy film "foreign female spies are single-minded vixens who apparently place personal or national interests above family" (Brady 2009: 113), Elizabeth's maternity is genuine, possibly a result of her "Americanization' or a characteristic that makes her more believable and closer to contemporary women. This apparent mutation of the soulless Soviet agent into a caring mother is only another facet of the multiple facets that a real woman should have. Elizabeth cannot be interpreted as only belonging to the 'wrong side', as the cold and amoral soviet spy that only follows orders portrayed in traditional spy movies. She is characterized as real, psychologically more complex than this type has previously been according to Mandel, who asserts that "the psychology of the crime story is generally too one dimensioned to allow complex and contradictory human beings to emerge" (1984: 65).

\section{The communist 'bad' girl}

The first episode offers a very complete presentation and portrayal of all the main characters and their motivations. The evolution of the Jennings - especially Elizabeth's - is observed and related to some subsequent episodes. In the first episode the series' primary focus is the articulation of Elizabeth's character. She is a human being with personal traumas such as the death of her father or the fact that she was raped. In contrast with Bratich's "isolated and abstracted hero" (2009: 135), Elizabeth does have a past and a personal history.

The very first scene in the series introduces her. In a dark mise-en-scene, the man is almost indistinguishable. The subjective camera shows what the man is looking at because the scene relies on close-ups that highlight Elizabeth's beauty. She is an attractive blonde, slender and sexy, and her appearance is closer to that of a famous actress than to that of a mother with teenage children. It corresponds to the role she is playing at that moment: a prostitute seducing a man in a bar. She is using sex to get information. Self-confident and firm, she does not show any emotion, but she controls and drives the situation to the point that she wants. 


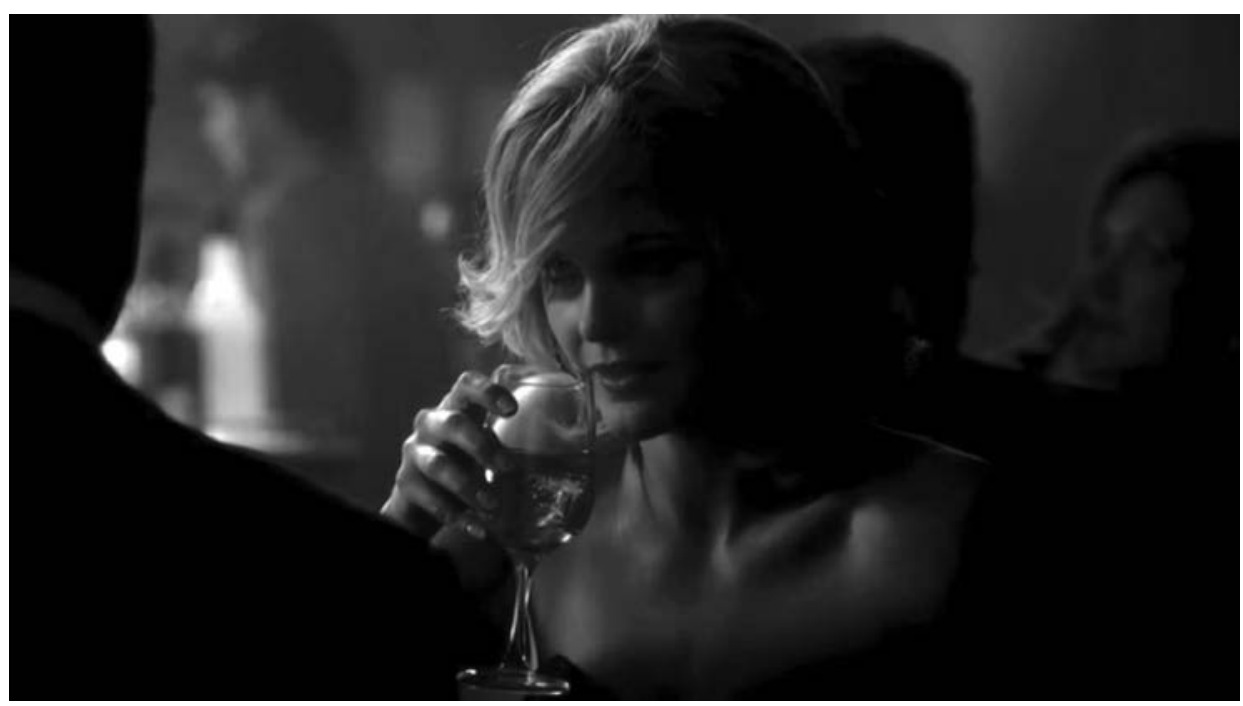

Figure 1. Screenshot. Elizabeth seducing a man to get information

There is an explicitly erotic scene, in which Elizabeth performs oral sex with the man she has just met. Maybe this is not very conventional behaviour, especially in the puritan US under Reagan doctrine (see Stossel's article "The Sexual Counterrevolution" 2017). Elizabeth acts like an experienced prostitute but her sexual disinhibition is not to be found, apparently at least, among middle-class housewives from the 1980s. She is presented as highly sexualized and ready to do whatever may be necessary for this man so that he will reveal his secrets. Up to this moment nothing contradicts the image of a sexualized and cold soviet spy, but when she has left the hotel room she throws her wig away in disgust. In only a few minutes in the first episode the audience learns that Elizabeth is not as cold as could be expected from a traditional Mata Hari type of spy. However, she is a professional, absolutely committed and loyal to the Soviet Union. In the departure point, the series presents Elizabeth's identity as based on her belonging to a specific political order (Hepburn 2005: 8).

The fact that this sexual disinhibition belongs to a non-American agent is not casual, according to Brady. In previous TV series such as Alias, with a CIA female agent as protagonist, exotic and foreign women, among them Russian spies, are depicted as sexually depraved and morally corrupt the moment they use sex as a tool to get information. The US American protagonist in Alias, Jennifer Garner, would never cross the line that separates sex from her work (Brady 2009: 112). Sex for the correct model of an American spy should be limited to the private sphere. It could be said that the fact that Elizabeth does not conform to this unwritten rule may be caused by her foreignness and also as a first subtle indication of the superiority of American morality over Soviet morality. Furthermore, Elizabeth was deprived from the ownership of her body and sexuality by her own KGB superiors. 


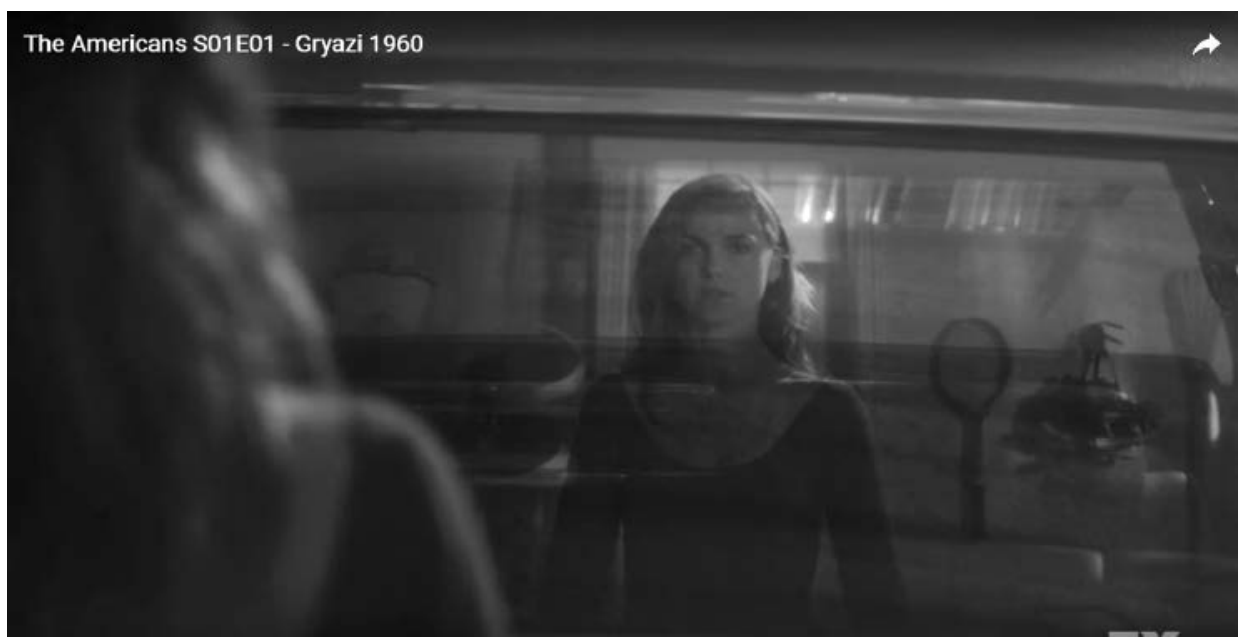

Figure 2. Screenshot: Elizabeth's rape flashback

In the family garage Elizabeth is about to open the boot of the car where she and Philip keep a defeated Soviet agent. As in the scene above, the subjective camera shows what Elizabeth is looking at. In this point of view shot, she looks at herself in the windscreen as if it were a mirror. In the scene there are two women in the darkness. One of them is surrounded by the typical familiar objects in a garage and the illuminated kitchen door appears behind her: the American mother vs the young Russian spy, since it is her young self that Elizabeth is recalling. The aesthetics of the shot parallel the duplicity of Elizabeth's personality. She needs to be detached from herself to be able to remember her youth, far away in time and space. The flashback is introduced to narrate when Elizabeth was a young aspirant doing her training in Russia. She was raped by her superior under the pretext of "being trained". She was defenseless because the only witness, also a male spy, turned a blind eye to what was happening. Even though she resisted, she was not strong enough to physically fight him off. Elizabeth was not only raped but also defeated as a 'professional' and humiliated. She suffered an aggression, usually the worst trauma for a woman. This important issue marks the moment she understood that her duties as a spy included the dispossession of any will. The KGB's demands seem to have no limit because Elizabeth is not even the owner of her body, life, desires and feelings. She follows orders without questioning them.

Sexual equality is neither present in the series nor in contemporary times. Women from the series' fictional past and from the factual present have to make more of an effort to acquire a position similar to men's. The female spy that the series introduces to the audience is perfectly aware of it and is ready to pay the price: she has to be not just as good as a male spy but even better to be considered the same. As White remarks: 
These narratives [the spy genre] are not only about the rise of women in the professions - or rather male paranoia about that perceived shift in gender roles - they also raise questions about the professional environments which women are beginning to inhabit in more significant numbers. (2007: 110)

In a mainly male world, the secret agents' field, Elizabeth has to leave behind her personal suffering as a woman to be competent enough to fulfill her duties towards her government because "without a sense of identification with the power they serve, there is no place for spies in society. Beyond their exclusion from the domestic sphere without submission to power spies are excluded from the professional sphere also" (Goodman 2016: 164).

\section{Subverting of reinforcing patriarchy?}

Elizabeth is both fetishised as a femme fatale and a committed family mother. The Americans can be read as endorsing certain feminist views but it also reinforces women's submission, commenting on some situations that are still so typical in contemporary women's lives. This model of 'having it all' has been sold to women in contemporary times. Competitiveness is nowadays an essential part of most professional women's lives, who at the same time do not renounce their 'natural' role as mothers in charge of the reproduction of the species. These professional women share their lives with males who are, in general, much less committed to their roles as fathers. Several sociological studies and evidence collected by Fagan in her study support this idea:

Women are significantly more likely to experience high levels of family interference with work when they have high family demands, while men's levels of family demands do not affect their family interference with work. Women may still feel that they are primarily responsible for their family, and thus experience increased family interference with their work. (2012: 21)

In contrast with her husband, Elizabeth's point of departure as a KGB spy is absolutely faithful to Soviet ideals and she is unconditionally convinced of the righteousness of her mission, fiercely loyal to the Soviet Union. She is the flawless spy; she has no doubts whatsoever about her orders, even when Philip tries several times to convince her that defecting could be a solution, a way of finding their personal happiness. Philip, at least in the first season, has no ghosts in his past. He enjoys his life as an American father and husband - even though this is quite a contradictory image, he does not appear to be the 1980s average middle class man. It could be said that Philip is closer to a contemporary man who equates the personal and family sphere with the professional world. A contemporary model of a man who is more committed to things that were in the past only the responsibility of women. It is a model that belongs to western society, quite 
new and maybe not as extended as one could believe, because nowadays women are still mostly in charge of the household's functioning.

The Americans is set in the "backlash" era. The backlash, according to Susan Faludi, was an establishment and social reaction against feminist movements that advocated for a return to the past in women's rights: "By the mid ' 80 's, as resistance to women's rights acquired political and social acceptability, it passed into the popular culture" (Faludi 2006: 11). It was a time when politicians claimed that women had a 'choice': if women decided to renounce their professional ambitions it was their free choice. In newspapers, articles commented on how some women were relinquishing their high wages "in favor of the stroller-pushing suburban life" (Faludi 2006: X). In this historical context Elizabeth appears almost anachronistic, because she is not only a spy; she is a 'legal' and visible working woman in a travel agency and, at the same time, she is tidy, attractive, a perfect cook, housewife and mother. In contrast, her American counterpart - the CIA agent's wife Sandra - remains at home and is only a housewife. As Weichlein explains, in the 'homeward bound' Cold War culture, middle class suburban women created a "secure psychological fortress" to resist the attacks of "dangerous social forces like women's sexuality, homosexuality, labor unions and civil rights activism" (2006: 55). Elizabeth, paradoxically both embraces and subverts the culture of domestic containment with her behaviour, not only as a spy but also as a 'modern' working woman.

\section{Ideology vs moral: social vs domestic}

Instead of Elizabeth, it is Philip who flirts with the idea of defecting when he learns how much money he could be paid by the FBI. But it is not the money that tempts him, it is the possibility of becoming a real citizen, father and husband. Whereas Philip is presented from the very beginning as fully conscious of his desire to be a family man, giving priority to the private sphere, Elizabeth has to evolve before starting to have doubts about her work. As Smiley says in the Tinker Tailor Soldier Spy film "a fanatic always conceals a secret doubt". Unlike Elizabeth, Philip has been somehow 'contaminated' by the American way of life and he enjoys it. $\mathrm{He}$ would be very willing to leave his life as a spy and just be a father and husband. When it comes to his family his professional ambitions as a spy come second. His ultra-vulnerability to western consumer culture 'contamination' could be due to the fact that he made less of an effort than Elizabeth to become a covert agent. Perhaps the path to the present was less arduous for him as a male spy than for Elizabeth as a woman. Being faithful to Russia can be understood not only as a question of political commitment but also as a gender issue. Elizabeth's road as a female spy was fraught with difficulties. The hard process that she went through is shown in several flashbacks. Elizabeth had to overcome long hard work to be what she is at the beginning of The Americans, but she is deeply convinced, she has blind faith, not only in the Communist political system but also in her KGB superiors. 
But, is there room in all of this for blind loyalty to the KGB? Although Elizabeth has no doubts, in the episode entitled "Trust Me" it becomes obvious that her superiors may not deserve such loyalty. Claudia (Margo Martindale), her KGB supervisor, orders some KGB agents to pass themselves off as FBI agents and to kidnap Elizabeth and Philip, torturing them to put their faithfulness to the Soviet Intelligence to the test because they suspect there is a mole. ${ }^{3}$ Elizabeth's torture is mainly psychological and based on her private sphere. She is locked in a room with the walls plastered with photos of her children. Claudia is perfectly aware that this is, apparently, her only weakness, her concern about Page and Henry's welfare. This episode is also a good example of the 'uncanny' in the series, the fear of something which, according to Goodman, "is familiar and yet unusual" because as the spy "is never at ease within the domain of his own home; instead his fear of being unmasked causes tension between his outward performance and his interior reality" (2016: 153). Elizabeth's weak spot is her family. It is in defense of her private sphere and in conflict with her duties as a spy that Elizabeth beats Claudia without mercy. She learns that her firm loyalty has been rewarded in the worst possible way - the materialization of her children's vulnerability. When she imagines them in danger without any protection and it is the mother who defends them, not the spy.

But even under this extreme psychological torture the spy eventually prevails, she does not give any information to the KGB agents posing as the FBI, she remains loyal, like Philip. Even though the spy is alone in the end, no organization supports the spy that is caught. Both of them, Elizabeth and Philip, have been trained to endure torture, they are professionals. And it is the kind of torture chosen for each of them that gives the audience clues about their inner self. While Elizabeth is confronted with the image of her unprotected children, her Achilles heel, Philip receives physical torture without any result. He is treated with callousness, beaten and almost drowned when finally, the impostors threaten to beat Elizabeth in front of him. They take it for granted that Philip could probably not stand the sight of Elizabeth being mistreated. That this is his main weakness. And we shall never know what his final reaction would have been because Claudia orders the agents to stop before Elizabeth can come to any harm.

After asking Elizabeth what type of treatment she has received, Philip concludes that Claudia trusts Elizabeth more than him because, as Elizabeth told Claudia, Philip was fully adapted to the American way of life. This revelation damages the fragile love relationship between them. As Philbrick's character affirms in I Led Three Lives, communism "does not trust anyone; therefore, it is the duty of even married couples to distrust each other" (Weichlein 2017: 43). Later on, they break off their relationship because they can no longer trust each other.

What is very remarkable is how they draw the line between their work (public sphere) and their growing love relationship (private sphere). Both of them tolerate the other having sex with other partners, as part of their investigation duties, but neither of them understands the other having sex only for pleasure. This compartmented vision of the individual, divided into two, the public self 
and the private one, seems to connect with the contemporary man and woman. Ironically, the Jennings understand lies, murder, promiscuous sex and lack of morality in general as an inseparable part of their work, their public/hidden self, as Soviet agents, but in the domestic sphere they preserve a very conventional idea of marriage and family more in accordance with the American model, which is why Elizabeth decides to live apart when she learns that Philip has had sex with Irina, his ex-girlfriend and a soviet agent as well. Elizabeth tolerates Philip having sex for spying purposes but not for pleasure or sentimental reasons. It could be said that they expect a private pact of faithfulness, in the only part of their lives in which they can be individuals with a complete identity, without lies - their private lives. Elizabeth and Philip make a strong distinction between their real life in which they can take decisions with freedom - their private life - and, on the other hand, their work/profession, subject to the orders and interests of their government a public life which is totally fake. The difficulty to combine what they perceive as real and fake, built by obligations, is the same difficulty that many contemporary couples experience in the $21^{\text {st }}$ century. One may wonder if we always put our public lives, professional careers and economic success first to the detriment of the private sphere which, at the end of the day, seems to be what leads to happiness.

The Jennings are objects, pawns in a game and only valuable while useful. Although the spirit of the series is not tragic because romance, love and family are present, there is an underlying tragedy in the fact that there is no way out for them. It is the conventional dark - gris - mood that is a distinctive characteristic of the spy genre. But there is one possibility of introducing colour and happiness in their lives: they should rely on each other. If they maintain their private sphere free of lies, their bonds firmly tied with trust and truth, what happens in their public life will not matter. Consequently, romanticism becomes the new and most important element in the formula. That is why in the last episode of the first season when Elizabeth, who has been shot, wounded and nearly caught asks Philip to go 'home' with their children. She figures out that they share a real home, with a real family and Philip's place is there, with their children, taking care of them until she can go back and take up her role as a mother again. They are obliged to combine the spy world with the family and go on with their lives of lying and murdering but what makes them feel worried or happy is their domestic life, their family. They try to live for the moment.

The problem is that they cannot get rid of lies even in their private space. Their own children are, on the one hand, part of the covert and, on the other hand, American citizens living with the enemy. Philip and Elizabeth have to hide things and constantly lie to their own son and daughter, not only to protect them, but to be protected against them. As Brady points out: "as family is implicated in the deception, abuse and nationalism inherent in the spy genre, a very particular notion of familial relations and the ways in which they are linked up with nationhood is expressed" (2009: 113). The Jennings, working for a communist government and apparently with very solid communist principles, have to face the fact that their 
children are being brought up within the capitalist system and are by definition their enemies. This would be another example of how the state, the public sphere, intervenes and distorts private life, the almost impossible adjustment between the private and the public.

\section{Conclusion}

The Americans departs from the conventions of a genre that was developed in the Cold War period, marked by fear and anxiety. Nowadays the genre has been recovered and proves useful to convey the pessimistic mood and a frame to develop current general worries in western society. By presenting a new aspect of the Cold War, trying to be more realistic and less 'patriotic' than previous spy movies and series, The Americans can be seen as part of what Collins calls "new sincerity" rather than a post-modernist recreation of a genre and the past. The series is generically genuine since it preserves the classical conventions that initially defined the genre, even if it subverts some of them to make the series more suitable for the $21^{\text {st }}$ century.

The introduction of a female spy, Elizabeth, as a leading character in the series is an extraordinary resource that allows the incorporation of new subjects and concerns. The Americans expands the possibilities of spy films by laying more emphasis on private life and adapting the model to a contemporary society in which individuals are as isolated as cover spies and can identify with Philip Jennings, a spy willing to betray his ideology in pursuit of his self-interest. Although establishing a binary world made up of symmetrical oppositions, The Americans departs from the moral concepts of right and wrong to present characters with moral ambiguity and conflicts. Politics, economics, global and gender issues are the backdrop for the most relevant part of the plot, the characters' personal lives and relationships. Whether American or Russian spies, it seems that it is in the private field, in affective relationships that humans look for fulfillment.

The Jennings are both unrepentant killers and concerned parents, moral ambiguity is present in each second of their lives. In season one, Elizabeth and Philip have surrendered their public life to the pressure exerted by their own society, the Soviet one, while their inner sides struggle to achieve happiness in the private field: love and family. This is what the Jennings have in common with spectators, the contradictions between our natural and family side and what society expects us to be and do. They seem to have endorsed the statement that Margaret Thatcher made in 1987, when she claimed that there was "no such thing as society, only men, women and families" (n.p.). As a consequence of 9/11, and a generalized economic crisis, society today has lost confidence in the power of politics and politicians to rule our lives and still less to deserve our trust. Consequently, it is perfectly understandable to look for happiness in all spheres only depending on personal, individual rule, and leaving moral principles for the private field. Moral ambiguity therefore becomes a right option for the public sphere. 
However, in terms of politics and the vision of the American way of life the series does not send out a monolithic message. On the contrary, it is rather ambivalent. On the one hand, it seems to criticize the system, especially the most conservative views, and, on the other hand, it subtly praises US culture. It shows how Soviet spies become 'humanized' under American cultural influence whereas their morally questionable behaviour is a consequence/indicator of their foreign origins. In that sense the series remains faithful to the American double standard of morality in which violence is an essential part of their identity whereas certain sexual practices and female promiscuity are not tolerable for real American citizens, only for foreigners like the Jennings. It can also be said that the series, as an American product, although critical of the American political system and politics, is not neutral in the sense that it presents the American model of life as a positive influence on Philip, which makes him less of a fanatic and more human in comparison with the initial image of Elizabeth, who is presented as more radical, almost tailor-made for the Soviet system. Furthermore, also ambivalent in gender themes, the series' innovation through the incorporation of a mother/wife/whore/ spy calls for a feminist analysis. Due to the complexity and multiplicity of Elizabeth's character, her contradictions and inner struggles, the series can be read as feminist and reactionary at the same time. Like Alias, The Americans offers its audience "something other than contained femininity. That is not to say that the series is "feminist $[\ldots]$ simply that these diversions from the mainstream open up cracks in the facade of heteropatriarchy" (White 2007: 138).

But here the audience has empathized with the mole's point of view and takes Philip and Elizabeth's side even though as models the Jennings are morally ambiguous. The model of the US that is put across is not so exemplary and Elizabeth and Philip's worries are familiar and known to us, from the problems with their children to their marital crisis. To summarise, The Americans is a truthful spy show, but only on the surface, the core is romance and the family.

\section{Notes}

$1 \quad$ Reagan's ideology can be summarized in 11 main principles: "Freedom, Faith, The sanctity and dignity of human life, American exceptionalism, The Founder's wisdom and vision, Lower taxes, Limited government, Peace through strength, Anti-communism and belief in the individual" (in Weingarten 2014: n.p.). As Lakoff articulates, people voted for Reagan in the 1980s because they identified with him. Voters trusted Reagan the man and found a connection between themselves and his world view, although sometimes these voters did not agree with his policies (2006: 7).

2 The Bond films also incorporated humor and parody to the formula: "the very notion that the masculine agent might act directly on behalf of the state becomes the principal source of humor and critique" (Kackman 2005: xxxvi).

3 Claudia's wickedness is not very surprising but a convention of the genre according to White: "older women in these series tend to occupy a sinister role ... they are women whose role in the professional sphere has become their identity, but they have conformed to its demands rather than shifting the terms on which it operates" (2007: 143). 


\section{Acknowledgements}

The author acknowledges financial support from the Spanish Ministry of Economy and Competitiveness (FFI2015-63506-P), the Regional Government of Aragón and the European Social Fund (H03_17R).

\section{References}

Bleton, Paul (2017) Machiavelli's angels hiding in plain sight: Media culture and French spy fiction of the Cold War. In: Jarausch, Konrad H, Christian F. Ostermann and Andreas Etges (eds.) The Cold War: Historiography, Memory and Representation. Berlin and Boston: Gruyter, 134-151.

Booth, Alan R. (1991) The development of the espionage film. In: Wark, Wesley K. (ed.) Spy fiction, Spy films and real intelligence. London: Frank Cass 1td, 136-160.

Brady, Miranda J. (2009) Family, nation and the female secret agent in Alias. In: Parker, Jeremy (ed.) Secret Agents. Popular Icon Beyond James Bond. New York: Peter Lang Publishing, 11132.

Bratich, Jack Z. (2009) Spies like us: Secret agency and popular occulture. In: Parker, Jeremy (ed.) Secret Agents. Popular Icon Beyond James Bond. New York: Peter Lang Publishing,133-62.

Classen, Cristoph (2011) The Cold War in the cinema: The boom in spy films in the 1960's, its causes and implications. The Celluloid Curtain, 9 Sept 2011. Available online at: http://www.bpb. de/gesellschaft/kultur/filmbildung/63199/the-cold-war-in-the-cinema. Accessed on 6 April 2017.

Collins, Jim, Hilary Radner and Ava Preacher Collins (1993) Film Theory Goes to the Movies. New York: Routledge.

D'Acci, Julie (1994) Defining Women: Television and the Case of Cagney and Lacey. Wisconsin: The University of North Carolina Press.

Fagan, Colette et al (2012) The influence of working time arrangements on work-life integration or 'balance': A review of the international evidence. Conditions of Work and Employment Series. No 32, 14 August 2012. Geneva: International Labour Office. Available online at: http://www.ilo. org/travail/whatwedo/publications/WCMS_187306/lang--en/index.htm. Accessed 20 May 2015. Accessed on 15 May 2016.

Faludi, Susan (2006) Backlash: The Undeclared War against American Women. The $15^{\text {th }}$ Anniversary Edition. New York: Three Rivers Press.

Goodman, Sam (2016) British Spy Fiction and the End of Empire. New York and London: Routledge.

Hepburn, Allan (2005) Intrigue: Espionage and Culture. New Haven and London: Yale University Press.

Jarausch, Konrad H., Christian F. Ostermann and Andreas Etges (2017) Rethinking, representing and remembering the Cold War: Some cultural perspectives. In: Jarausch, Konrad H., Christian F. Ostermann and Andreas Etges (eds.) The Cold War: Historiography, Memory and Representation. Berlin and Boston: Gruyter, 1-18.

Kackman, Michael (2005) Citizen Spy. Television, Espionage and Cold War Culture. Minnesota: University of Minnesota Press.

Lakoff, George (2006) Thinking points: Communicating our American values and vision. Faculty Web Sites at the University of Virginia. Available at http://www.faculty.virginia.edu/haidtlab/lakoff.thinking-points.pdf. Accessed on 25 March 2015

Lisanti, Tom and Louis Paul (2002) Films Fatales: Women in Espionage Films and Television, 1963-1973. Jefferson, North Carolina, and London: McFarland.

Mandel, Ernest (1984) Delightful Murder: A Social History of the Crime Story. Bristol: Pluto Press Ltd. 
Nichols-Pethick, Jonathan (2012) TV Cops. The Contemporary American Television Drama. New York and London: Routledge.

Stossel, Scott (1997) The sexual counterrevolution. The American Prospect July/August 1997. Available at http://prospect.org/article/sexual-counterrevolution. Accessed on 5 April 2017.

Strinati, Dominic (2005) An Introduction to Theories of Popular Culture. London: Routledge.

Thatcher, Margaret (1987) No such a thing as society. Margaret Thatcher Foundation. Available at http://www.margaretthatcher.org. Accessed on 4 April 2015.

Walter, Natasha (2016) Why fiction needs more female spies. The Guardian 11 June 2016. Available at https://www.theguardian.com/books/2016/jun/11/why-fiction-needs-more-female-spies. Accessed on 6 April 2017.

Weichlein, Siegfried (2006) Representing and recording. In: Haynes, John Earl and Harvey Klehr (eds.) Citizen Spy: Television, Espionage, and Cold War Culture. Minneapolis: University of Minnesota Press.

Weingarten, Benjamin (2014) The 11 principles of a Reagan conservative. The Blaze 3 March 2014. Available at http://www.theblaze.com/news/2014/03/03/the-11-principles-of-a-reagan-conservative/. Accessed on 10 April 2017.

White, Rosie (2007) Violent Femmes. Women as Spies in Popular Culture, London and New York: Routledge.

\section{Films and series}

Alias (2001-2006): Created by J.J. Abrams, performance by Jenifer Garner, ABC.

Cagney \& Lacey (1981-1988) Produced by Barney Rosenzweig, performance by Sharon Gless and Tyne Daly.

Mr. and Mrs. Smith (2005) Directed by Doug Liman.

Nikita (1990) Directed by Luc Besson.

Nikita (2010-2013) Created by Craig Silverstein, performance by Maggie Q. CW.

The Americans: Season 1 (2013) Created by Joe Weisberg, performance by Keri Russell and Matthew Rhys, $20^{\text {th }}$ Century Fox.

The Spy Who Came in from the Cold (1965): Directed by Martin Ritt.

Tinker Tailor Soldier Spy (2011): Directed by Tomas Alfredson.

Esther MuÑoz-GonZÁLez is a research fellow at the Department of English and German Philology of the University of Zaragoza (Spain). She has published research articles in journals of the field such as The Journal of English Studies and ES Review, Spanish Journal of English Studies. She is currently engaged in writing her $\mathrm{PhD}$ on the work of Margaret Atwood. Her main research interests lie in contemporary US fiction from a posthumanist perspective combined with trauma theory with special interest in dystopian representations of the future and cli-fiction.

Address: Esther Muñoz-González. Departamento de Filología Inglesa y Alemana. Universidad de Zaragoza. Facultad de Filosofía y Letras. Pedro Cerbuna 12, 50009 Zaragoza, España. [email: emunoz@unizar.es] 